\title{
Influence of Partial Replacement of Nickel by Nitrogen on Microstructure and Mechanical Properties of Austenitic Stainless Steel
}

\author{
A. Ahmed, ${ }^{1}$ S. N. Ghali, ${ }^{1}$ M. Eissa, ${ }^{1}$ and S. A. El Badry ${ }^{2}$ \\ ${ }^{1}$ Steel and Ferroalloys Department, Central Metallurgical Research and Development Institute, Helwan 11421, Egypt \\ ${ }^{2}$ Physics Department, Faculty of Science, Al-Azhar University, Nasr City, Cairo 11884, Egypt
}

Correspondence should be addressed to A. Ahmed, azzaazza40@yahoo.com

Received 4 August 2011; Accepted 31 August 2011

Academic Editor: Gerhard Sauthoff

Copyright (C) 2011 A. Ahmed et al. This is an open access article distributed under the Creative Commons Attribution License, which permits unrestricted use, distribution, and reproduction in any medium, provided the original work is properly cited.

\begin{abstract}
A new modified austenitic stainless steel has been developed through partial replacement of nickel by nitrogen. Nitrogen stainless steel was produced in $10 \mathrm{~kg}$ induction furnace under nitrogen pressure, while reference one, AISI 316 steel grade, was produced in open-induction furnace. Both were cast and hot forged, and the total nitrogen was determined. Furthermore, the produced forged steels were subjected to solution treatment at different temperatures. The microstructure of produced stainless steels was observed. The X-ray diffractmeter and Mossbauer effect spectroscopy were used to follow the phase change in reference and modified steels after different heat treatment temperatures. The influence of grain-size, soluble, and insoluble nitrogen on tensile strength and hardness was investigated. The major phase in the modified steel has a fcc structure similar to the reference one, but with finer grains and more expanded lattice. The yield strength and hardness of the nitrogen-modified stainless steel are higher than the reference steel. On the other hand, the increase of nitrogen content deteriorates the steel ductility.
\end{abstract}

\section{Introduction}

Over the past few decades, there is a trend in the that world aims at the replacement of nickel by nitrogen as an austenitic stabilizer element [1-4], as nitrogen is considered as the strongest austenitic stabilizer element among all the austenitic stabilizers, that is, $\mathrm{C}, \mathrm{Mn}, \mathrm{Ni}$, and $\mathrm{Cu}$.

The partial replacement of nickel by nitrogen increases mechanical properties, besides the improvement of corrosion resistance [5].

High-nitrogen stainless steels can be produced in the liquid state [6] by different techniques such as induction furnace, electric arc furnace, gas bubbling in liquid steels, pressure electroslag remelting (PESR), plasma arc melting, and arc-slag melting. Each melting technique has advantages and disadvantages. For example, PESR is complicated and expensive. On the other hand, nitrogen gas alloying and addition of nitrided ferroalloys under normal atmospheric conditions is a simple and feasible method, but the nitrogen content of produced steel is limited. To increase the nitrogen content, the nitrogen partial pressure must be increased. This can take place through melting in induction furnace under nitrogen pressure [6].

The main problem - faced by steel-making researchersis not only how to introduce nitrogen into molten stainless steel but also how to keep it during the solidification and heat treatment.

This paper aims at developing an innovating grade of austenitic stainless steel by nickel partial replacement with nitrogen produced in induction furnace under nitrogen pressure. In this study, the phase transformations, resulting from this partial replacement, were examined. Furthermore, the dissolution of nitride precipitates and other phase transformations that occur during heat treatment and its effect on the mechanical properties have been investigated.

\section{Experimental}

Two types of stainless steel, reference and modified stainless steels, with different contents of nickel and nitrogen were melted in $10 \mathrm{~kg}$ induction furnace type IF-001. The reference 
TABLE 1: Chemical composition of the produced stainless steels, wt $\%$.

\begin{tabular}{lccccccccc}
\hline Steel type & $\mathrm{C}$ & $\mathrm{Si}$ & $\mathrm{Mn}$ & $\mathrm{Cr}$ & $\mathrm{Mo}$ & $\mathrm{Ni}$ & $\mathrm{N}$ & $\mathrm{P}$ & $\mathrm{S}$ \\
\hline Reference steel & 0.077 & 1.44 & 1.41 & 17.98 & 2.19 & 14.1 & 0.010 & 0.017 & 0.013 \\
Modified steel & 0.080 & 1.53 & 1.24 & 17.61 & 2.87 & 8.93 & 0.379 & 0.024 & 0.013 \\
\hline
\end{tabular}

TABLE 2: Weight percent of total NMI and precipitates.

\begin{tabular}{lcccc}
\hline & \multicolumn{2}{c}{ Reference steel heat-treated at } & \multicolumn{2}{c}{ Modified steel heat-treated at } \\
Sample & $1100^{\circ} \mathrm{C}$ & $1200^{\circ} \mathrm{C}$ & $1100^{\circ} \mathrm{C}$ & $1200^{\circ} \mathrm{C}$ \\
\hline NMI and precipitates wt $\%$ & 0.44 & 0.21 & 0.57 & 0.32 \\
\hline
\end{tabular}

TABLE 3: Insoluble and soluble nitrogen in modified nitrogen stainless steel after different heat treatment temperatures.

\begin{tabular}{|c|c|c|c|c|}
\hline \multirow{2}{*}{ Nitrogen status } & \multicolumn{2}{|c|}{ Modified stainless steel treated at $1100^{\circ} \mathrm{C}$} & \multicolumn{2}{|c|}{ Modified stainless steel treated at $1200^{\circ} \mathrm{C}$} \\
\hline & $\begin{array}{c}\text { Nitrogen content, } \\
\text { wt } \%\end{array}$ & $\begin{array}{c}\% \text { relative to the total } \\
\text { nitrogen }\end{array}$ & Nitrogen content, wt $\%$ & $\begin{array}{c}\% \text { relative to the total } \\
\text { nitrogen }\end{array}$ \\
\hline Soluble nitrogen content & 0.362 & 95.5 & 0.368 & 97.1 \\
\hline $\begin{array}{l}\text { Insoluble nitrogen } \\
\text { (nitrides) content }\end{array}$ & 0.017 & 4.5 & 0.011 & 2.9 \\
\hline
\end{tabular}

steel was melted in open air, while modified austenitic stainless steel with high nitrogen was melted under nitrogen pressure. Both molten metals were cast in refractory sand mould at $1600^{\circ} \mathrm{C}$, in air and under nitrogen pressure, respectively. The produced ingots, with square cross-section dimensions $67 \mathrm{~mm} \times 67 \mathrm{~mm}$, were recharged into reheating furnace. The ingots were heated up to $1150^{\circ} \mathrm{C}$ and held for 1 hour. The forging process started at $1150^{\circ} \mathrm{C}$ by using load of one ton free forging (dieing) to produce square rods of $25 \times 25 \mathrm{~mm}^{2}$. The chemical compositions of produced steels were determined by using spectroscopic analysis. The heat treatment processes of investigated stainless steels were carried out at $1100^{\circ} \mathrm{C}$, and $1200^{\circ} \mathrm{C}$, kept for one hour, followed by water quenching. The quenched stainless steels were tempered at $300^{\circ} \mathrm{C}$ for one hour. Hardness (HV) tests were carried out on polished stainless steel samples. Tensile tests were carried out at room temperature for stainless steel samples. Microstructure examination of heat-treated steels was carried out using optical microscope. Samples of tempered stainless steels after heat treatment were subjected to electrolytic dissolution for isolation of precipitates and nonmetallic inclusions. Nonmetallic inclusions were examined using X-ray diffractometer. The kjeldahl method [7] was used to determine the total and insoluble nitrogen content in modified stainless steels.

Mossbauer effect spectroscopy was used to follow the phase change in reference and modified steels after heat treatment at $1100^{\circ} \mathrm{C}$ and $1200^{\circ} \mathrm{C}$. The spectra of the studied samples were recorded at room temperature in a transmission geometry using a standard constant acceleration spectrometer. A $25 \mathrm{mCi} 57 \mathrm{Co}$ radioactive source in $\mathrm{Rh}$ matrix was used. The spectra were analyzed using a computer program based on both Lorentzian and Gaussian line shapes which can fit up to forty ME absorption peeks in the same spectrum. The isomer shifts (ISs) were calculated with respect to a metallic iron calibration spectrum.

\section{Results and Discussion}

The chemical compositions of reference and modified stainless steels are given in Table 1.

\subsection{Effect of Heat Treatment on Precipitates and Nonmetallic} Inclusions. The precipitates and nonmetallic inclusions of stainless steels were isolated, collected, and analyzed. The weight percentage of precipitates of $50 \mathrm{gm}$ dissolved steels was determined and given in Table 2. The nonmetallic inclusions were investigated by XRD. The wt $\%$ of soluble and insoluble nitrogen in each sample of the modified steel was determined, and the percent of the soluble and insoluble nitrogen relative to the total nitrogen content was calculated (Table 3).

It is clear from Table 2 that the amount of NMI separated from the modified steel is higher than that of the reference one which may be due to the presence of nitrides inclusions.

These results were confirmed by the XRD examination of NMI, separated from reference steel and modified one. XRD examination showed that NMI separated from the reference steel consists mainly of iron and chromium oxides and some carbide, while the NMI separated from modified steel consists mainly of $\mathrm{Cr}_{2} \mathrm{~N}$ beside iron and chromium oxides. The peak of $\mathrm{Cr}_{2} \mathrm{~N}$ in modified steel heat-treated at $1100^{\circ} \mathrm{C}$ was found to be higher than that of steel heat-treated at $1200^{\circ} \mathrm{C}$. 


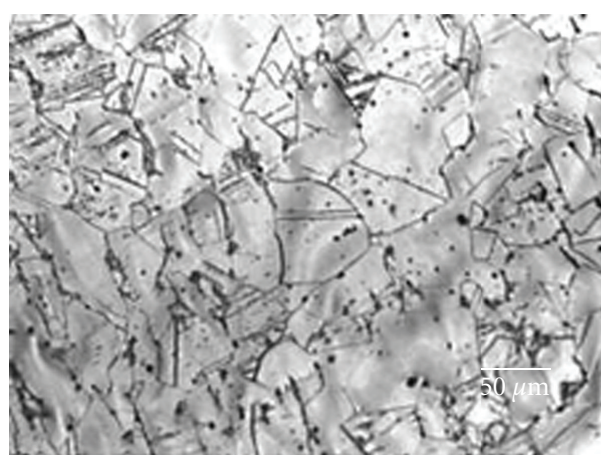

(a)

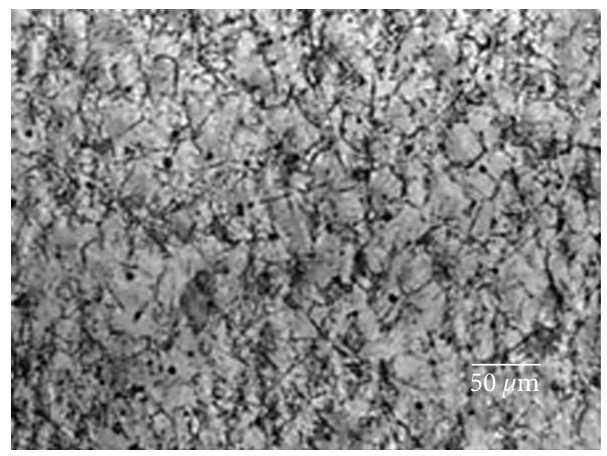

(c)

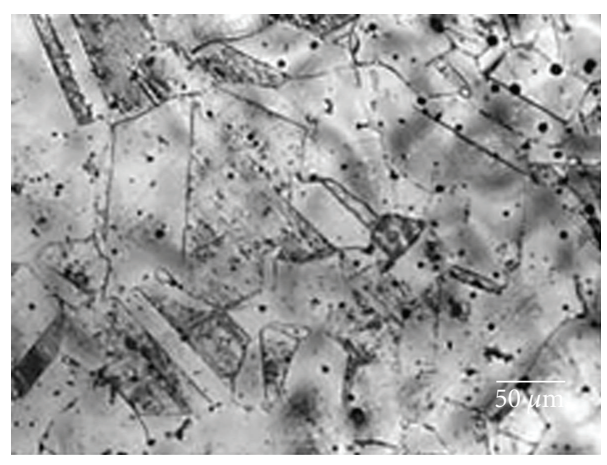

(b)



(d)

Figure 1: Microstructure of heat-treated (a) reference steel at $1100^{\circ} \mathrm{C}$, (b) reference steel at $1200^{\circ} \mathrm{C}$, (c) modified steel at $1100^{\circ} \mathrm{C}$, and $(\mathrm{d})$ modified steel at $1200^{\circ} \mathrm{C}$ (etched with $40 \%$ glycerin, $40 \%$ nitric acid, and $20 \%$ hyrochloric acid).

TABLE 4: Estimated grain size for the samples according to ASTM-E112.

\begin{tabular}{lcccc}
\hline & $\begin{array}{c}\text { Reference steel } \\
\text { heat-treated at } 1100^{\circ} \mathrm{C}\end{array}$ & $\begin{array}{c}\text { Reference steel } \\
\text { heat-treated at } 1200^{\circ} \mathrm{C}\end{array}$ & $\begin{array}{c}\text { Modified steel } \\
\text { heat-treated at } 1100^{\circ} \mathrm{C}\end{array}$ & $\begin{array}{c}\text { Modified steel } \\
\text { heat-treated at } 1200^{\circ} \mathrm{C}\end{array}$ \\
\hline Grain size, $\mu \mathrm{m}$ & 26 & 42 & 14 & 33 \\
\hline
\end{tabular}

The results in Table 3 show that, for modified stainless steel, the content of soluble nitrogen increases by increasing the heat treatment temperature, leading to a decrease of insoluble nitrogen (as nitrides), which could be attributed to the higher solubility of $\mathrm{Cr}_{2} \mathrm{~N}$ at higher temperature.

3.2. Microstructure. The microstructure and grain-size measurements for samples of the reference and modified steel heat-treated at $1100^{\circ} \mathrm{C}$ and $1200^{\circ} \mathrm{C}$ are shown in Figure 1 and Table 4. It is clear from this figure and table that the steels of identical analysis have different grain growth characteristics so that the austenitic grain size of the steel heat-treated at $1100^{\circ} \mathrm{C}$ is finer than that heat-treated at $1200^{\circ} \mathrm{C}$. On the other hand, examination of the microstructure at the same temperature showed that the grain size of the modified steel is finer compared with that of its corresponding reference one which was confirmed by the grain-size measurements.

These results coincide with the result of Di Schino and Kenny [8]. They concluded that the grain refinement was due to the presence of nitrogen, while increment of annealing temperature activates the grain boundary diffusion with consequent grain growth.

3.3. X-Ray Diffraction. XRD spectra of the reference and modified steel heat-treated at $1100^{\circ} \mathrm{C}$ and $1200^{\circ} \mathrm{C}$ are shown in Figure 2. In all investigated samples, the spectra clearly show the peaks due to austenitic phase, $\gamma$.

3.4. Mossbauer Effect. The Mossbauer spectra for the investigated heat-treated steels are presented in Figure 3, while the hyperfine parameters obtained by Mossbauer spectra curve fitting the samples are given in Table 5. Although all the obtained spectra show only single absorption peak indicating the presence of only nonmagnetic austenite phase, the peaks differ in their isomer shift (IS) and line width $(\Delta)$ values. The IS for the samples heat-treated at temperature $1100^{\circ} \mathrm{C}$ shows relatively higher values than that for samples heat-treated at temperature $1200^{\circ} \mathrm{C}$. This revealed that the austenite phase in the sample heat-treated at temperature $1200^{\circ} \mathrm{C}$ is more stable. This result appeared in complete agreement with the 


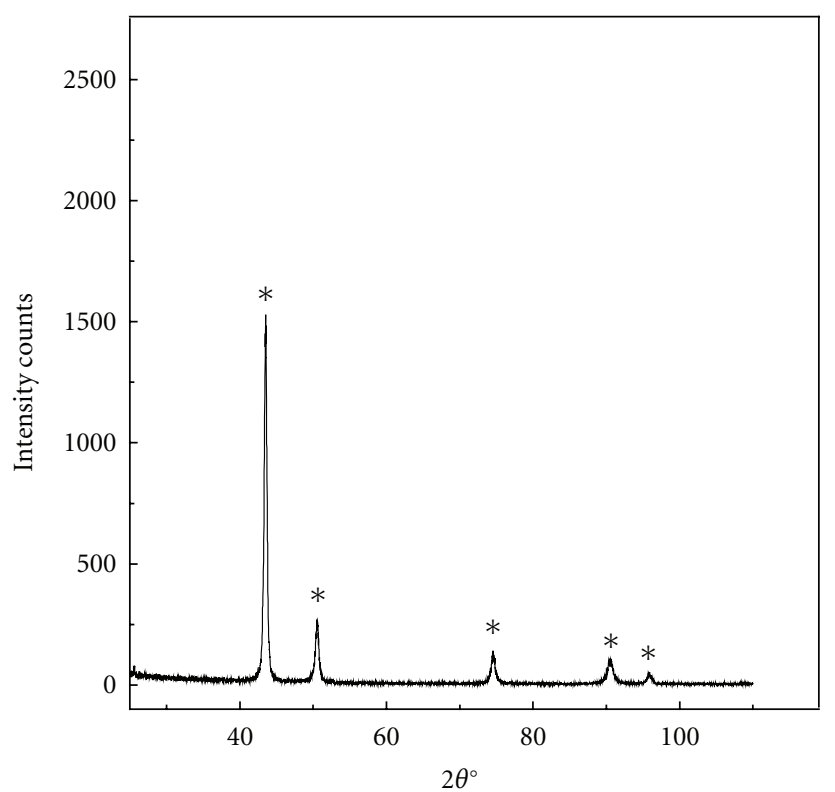

(a)

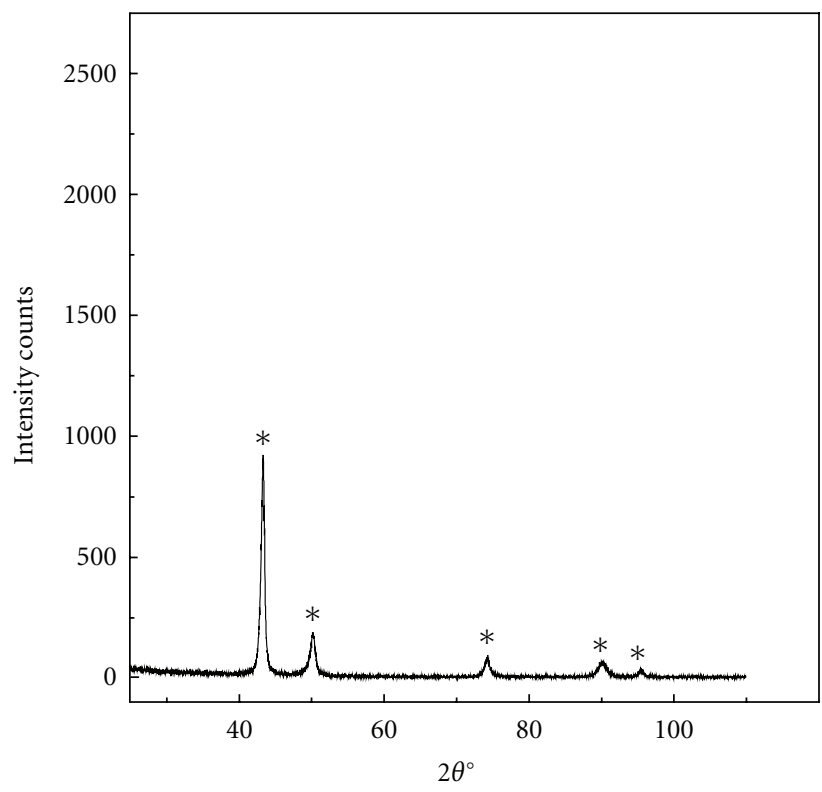

(c)



(b)

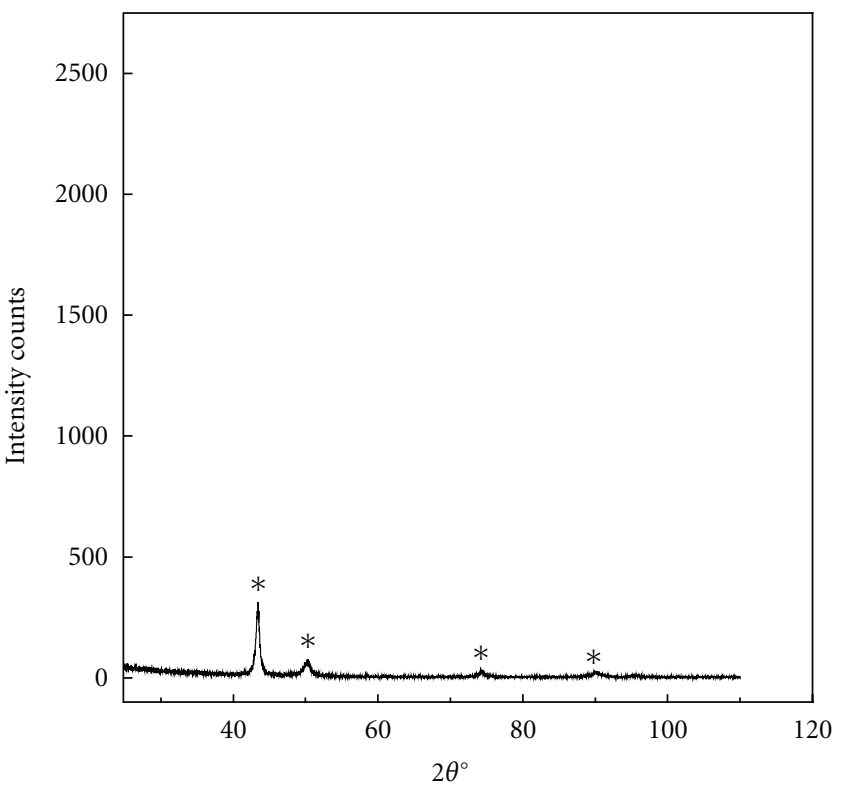

(d)

Figure 2: XRD spectra of heat-treated (a) reference steel at $1100^{\circ} \mathrm{C}$, (b) reference steel at $1200^{\circ} \mathrm{C}$, (c) modified steel at $1100^{\circ} \mathrm{C}$, and $(\mathrm{d})$ modified steel at $1200^{\circ} \mathrm{C},\left(^{*}\right)$ austenitic phase.

$\mathrm{X}$-ray results. At the same time, the reference steel has less IS values compared with that of the modified steel at the same heat treatment temperature. This indicates that the modified steel has more stable austenite phase.

The differences of the line width $(\Delta)$ values are expected to be associated with expanded austenite phase due to nitrogen interstitial solid solution.

3.5. Mechanical Properties. Comparison between the mechanical properties of reference steel and modified steel heattreated at $1100^{\circ} \mathrm{C}$ and $1200^{\circ} \mathrm{C}$ reflects the effect of nitrogen and NMIs on the mechanical properties of steel.
TABLE 5: The hyperfine parameters for the samples.

\begin{tabular}{lcc}
\hline Sample & Isomer shift (IS) & Line width $(\Delta)$ \\
\hline Reference steel at $1100^{\circ} \mathrm{C}$ & -0.0187 & 0.4549 \\
Reference steel at $1200^{\circ} \mathrm{C}$ & -0.0544 & 0.4696 \\
Modified steel at $1100^{\circ} \mathrm{C}$ & -0.005 & 0.4869 \\
Modified steel at $1200^{\circ} \mathrm{C}$ & -0.004 & 0.501 \\
\hline
\end{tabular}

3.6. Vickers Hardness. The differences of Vickers hardness of tested samples are shown in Figure 4. From the results given in Figure 4, it is clear that modified steel (containing 
TABLE 6: Tension results of different steel.

\begin{tabular}{lcccc}
\hline & $\begin{array}{c}\text { Reference steel } \\
\text { heat-treated at } 1100^{\circ} \mathrm{C}\end{array}$ & $\begin{array}{c}\text { Reference steel } \\
\text { heat-treated at } 1200^{\circ} \mathrm{C}\end{array}$ & $\begin{array}{c}\text { Modified steel } \\
\text { heat-treated at } 1100^{\circ} \mathrm{C}\end{array}$ & $\begin{array}{c}\text { Modified steel } \\
\text { heat-treated at } 1200^{\circ} \mathrm{C}\end{array}$ \\
\hline YS stress, $\mathrm{MPa}$ & 274 & 253 & 486 & 418 \\
Ultimate tensile strength, $\mathrm{MPa}$ & 552 & 538 & 824 & 752.917 \\
Elongation \% & 57 & 60 & 46 & 55.5000 \\
\hline
\end{tabular}

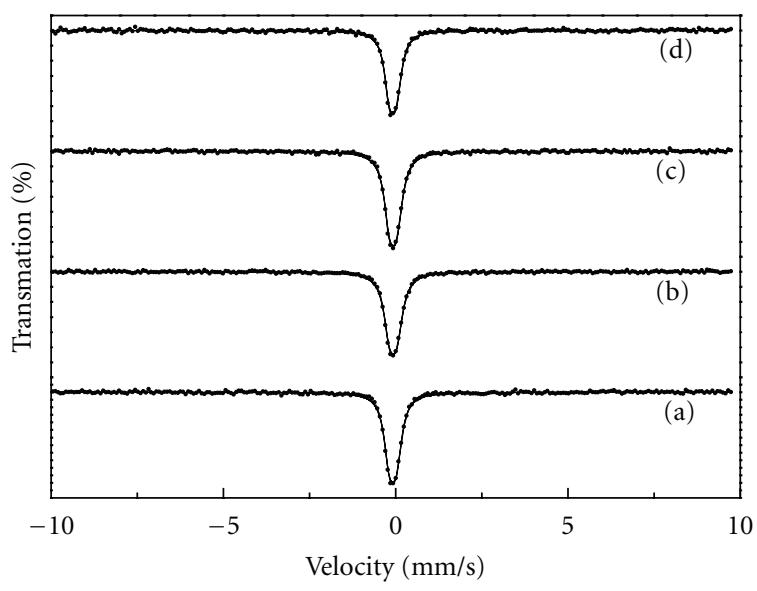

FIGURE 3: Mossbauer spectra of heat-treated (a) reference steel at $1100^{\circ} \mathrm{C}$, (b) reference steel at $1200^{\circ} \mathrm{C}$, (c) modified steel at $1100^{\circ} \mathrm{C}$, and (d) modified steel at $1200^{\circ} \mathrm{C}$.

nitrogen), generally, has higher hardness than the reference one. At the same time, for both types of steel, the hardness resulting from the heat treatment at $1200^{\circ} \mathrm{C}$ is always lower than that resulting from treatment at $1100^{\circ} \mathrm{C}$. These results seem to be due to the finer grain size of treated steels at lower temperature.

3.7. Tension Properties. The results of the tension testing (yield strength, ultimate tensile strength, and elongation \%) are given in Table 6. It is clear from the result that the highest yield strength of modified steel heat-treated at $1100^{\circ} \mathrm{C}$ is $486 \mathrm{MPa}$. This value is higher than that of reference steel at the same heat treatment condition which is $274 \mathrm{MPa}$ and that heat treated-at $1200^{\circ} \mathrm{C}, 253 \mathrm{MPa}$. On the other hand, with increasing heat treatment temperature of modified steel up to $1200^{\circ} \mathrm{C}$, the yield strength was found to decrease. The same trend is noticed with reference to ultimate tensile strength as it is clear from the result in the table. The higher values of the tensile strength of the modified steel compared with the reference one can be attributed to the nitrogen effect, as an alloying with nitrogen can be accompanied by an increase in the susceptibility of austenite to form packing defects (the energy of the defects decreased) [9] and simultaneously increases the frequency of appearance of annealing twins. The efficiency of grain boundary strengthening will depend on the total number of boundaries, which is responsible for the effective grain size. According to the Hall-Petch equations the finer grain size is commonly known to increase the strength of polycrystalline materials. In other words, the results confirm the effect of nitrogen in grain refinement

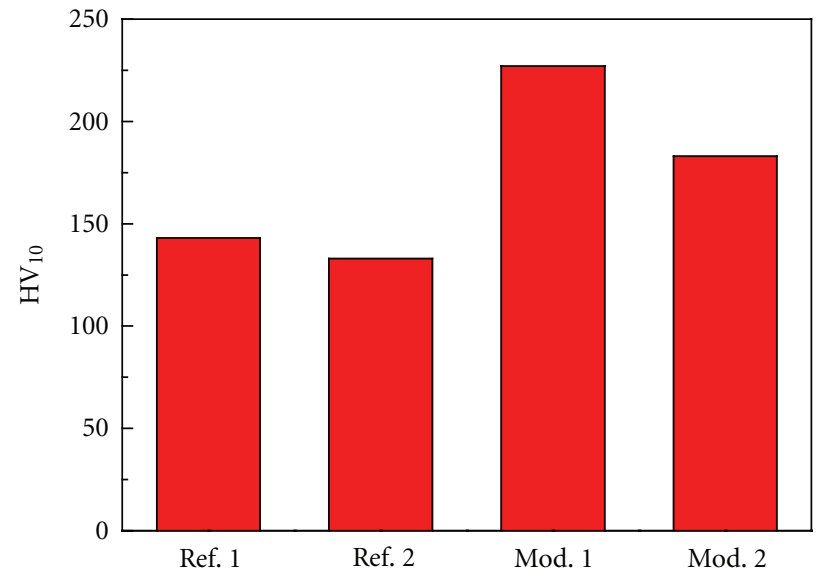

Figure 4: Comparison between Vickers hardness measurements where Ref. is reference steel and Mod. Is modified steel 1 and 2 heattreated at $1100^{\circ} \mathrm{C}$ and $1200^{\circ} \mathrm{C}$, respectively.

leading to higher strength of the modified nitrogen steel compared with the reference one.

As high levels of interstitial nitrogen can be retained in high-nitrogen austenitic stainless steels, they are thermally unstable and susceptible to nitride precipitation. The kinetics of precipitation is highly temperature dependent [9]. At lower heat treatment temperature, the solubility of nitrogen decreases and more nitrides are formed. The formation and presence of fine nitrides precipitate at the grain boundary or in the metal matrix and the loss of interstitial nitrogen would be expected to alter the yield strength of these modified steel heat-treated at $1100^{\circ} \mathrm{C}$. However, as previously mentioned, the modified steel heat-treated at $1100^{\circ} \mathrm{C}$ has smaller grain size than the modified steel heat-treated at $1200^{\circ} \mathrm{C}$. This lead to grain boundary strengthening. It seems that the strength increment due to grain boundary strengthening overcomes the strength decrement due to the losses in solid solution strengthening resulting in net increases in yield strength for modified steel heat-treated at $1100^{\circ} \mathrm{C}$.

It must be mentioned that although modified steel exhibits an extremely high strength compare with reference steel, it is susceptible to nitride-induced embrittlement. The presence of grain boundary and cellular nitrides has a detrimental effect on plasticity during the tensile ductility as it is clear from the elongation percent in Table 6.

\section{Conclusions}

A new modified grade of austenitic stainless steel has been developed through partial replacement of nickel by 
nitrogen. It was found that the partial replacement of nickel by nitrogen produces stainless steels with stable austenitic phase. The austenitic phase in the modified steel has fine grains and more expanded lattice. IS values indicated that the modified steel has more austenite stable phase. At the same time, the partial replacement of nickel by nitrogen improves the mechanical properties of austenitic stainless steels at room temperatures but decreases the ductility.

\section{References}

[1] J. W. Simmons, "Overview: high-nitrogen alloying of stainless steels," Materials Science and Engineering A, vol. 207, no. 2, pp. 159-169, 1996.

[2] N. Bernard, "Nitrogen contribution in passivity of high nitrogen stainless steels, passivation mechanisms and extrapolation to HNS," in Proceedings of the High Nitrogen Steels Conference, (HNS '04), p. 509, Ostend, Belgium, Austria, September 2004.

[3] L. Zhekova and T. Rashev, "Feasibility study on developing high-nitrogen steels by refining in suspended state under high pressure," Metallurgist, vol. 51, no. 1-2, pp. 90-96, 2007.

[4] J. Zhou-Hua, Z. Zu-Rui, I. Hua-Bing, and M. Qi-Feng, "Microstructural evolution and mechanical properties of aging high nitrogen austenitic stainless steels," International Journal of Minerals, Metallurgy and Materials, vol. 17, no. 6, p. 729, 2010.

[5] L. Hua-Bing, J. Zhou-Hua, and Z. Zu-Rui, "Effect of grain size on mechanical properties of nickel-free high nitrogen austenitic stainless steel," Journal of Iron and Steel Research International, vol. 16, no. 1, pp. 58-61, 1998.

[6] Y. F. Guo, S. H. Wang, and G. Q. Jin, "The study of nitrogen absorption with slagging in high nitrogen steels smelted by high pressure and bottom-blowing nitrogen," Advanced Materials Research, vol. 146-147, p. 1120, 2010.

[7] A. Vogel, A Textbook of Quantitative Inorganic Analysis Including Elementary Instrumental Analysis, Woolwich Polytechnic, London, UK, 1992.

[8] A. Di Schino and J. M. Kenny, "Grain refinement strengthening of a micro-crystalline high nitrogen austenitic stainless steel," Materials Letters, vol. 57, no. 12, pp. 1830-1834, 2003.

[9] K. O. Bazaleeva, Translated from metallovedenie i termicheskaya obrabotka metallov, no. 17, p. 17, 2005. 

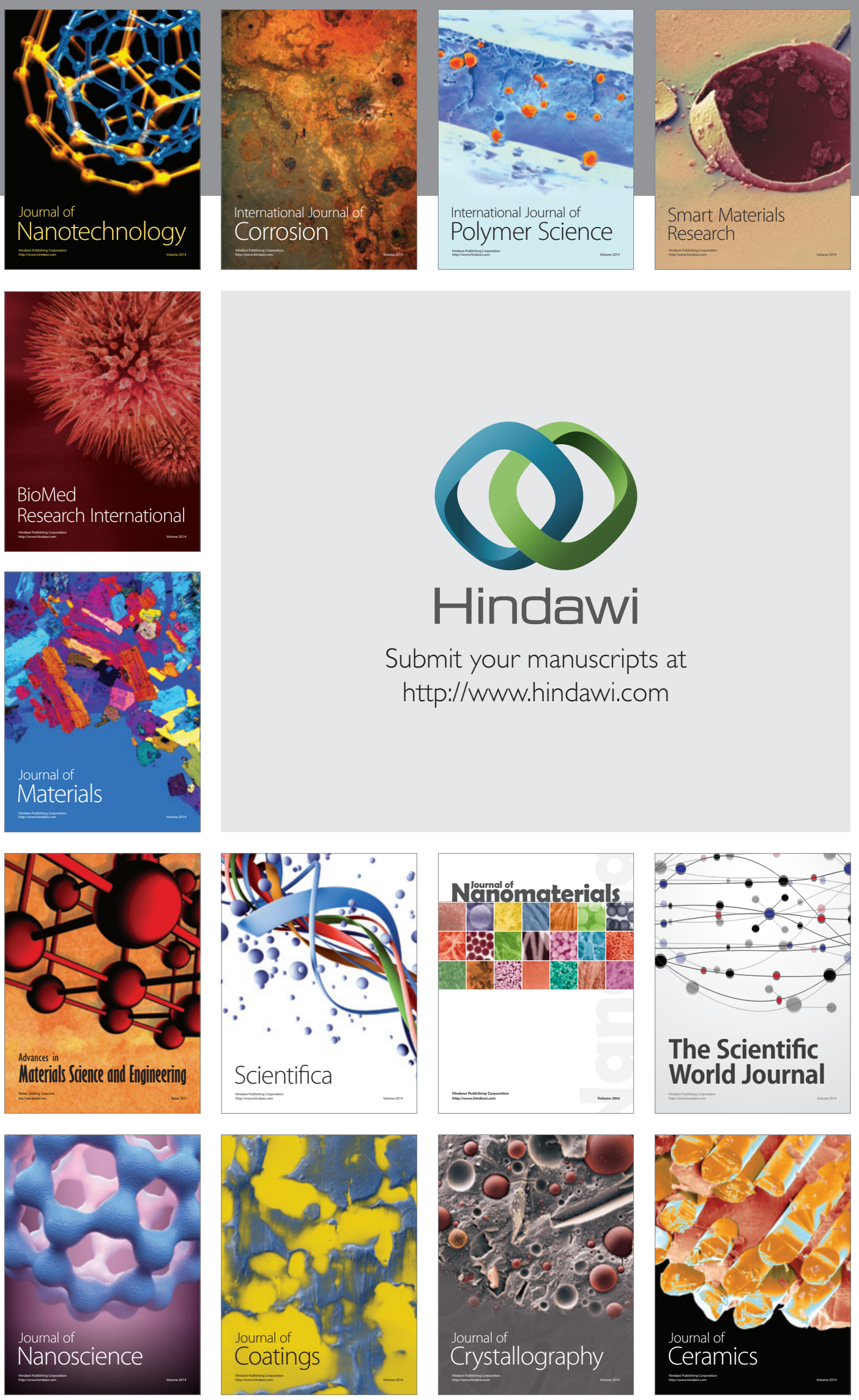

The Scientific World Journal

Submit your manuscripts at

http://www.hindawi.com

\section{World Journal}



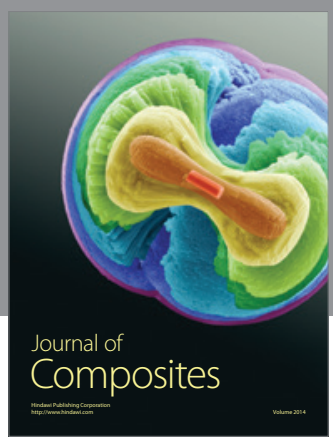
